\title{
Mathematical modeling of moisture removal from granules
}

\author{
D.M. Korinchuk (0000-0001-7752-4345) \\ National Technical University of Ukraine “Igor Sikorsky Kyiv Polytechnic Institute”, str. Polytechnichna, 39, \\ Bldg. 19, Kyiv, 03056, Ukraine \\ Tel.: +380996021632 \\ E-mail:ntps@i.ua
}

Article info: received 20.11.2020, revised 29.11.2020, accepted 14.12.2020

Korinchuk, D.M. (2020) Mathematical modeling of moisture removal from granules 4(49), DOI: 10.26909/ csl.4.2020.2

With modern world trends in the growth of consumption of products of various industries and the environmental situation, the problem of rational use of energy and raw materials in industrial production in order to obtain the maximum amount of finished product of a given quality. An important step in solving this problem is to create an adequate mathematical model of the process. A simplified model of the process of dehydration of the aqueous solution film on the surface of a single granule in the production of multilayer composites in a granulator dryer has been developed.

Simulation of pellet dehydration includes analysis of heat distribution in a spherical material and in a film of liquid (heat exchange) covering the sphere, and the process of evaporation of the mixture film (mass transfer), which take place simultaneously.

The results can be applied at the stages of design and testing of the granulator.

Key words: spherical material, covering the sphere, mixture film, mass transfer.

\section{Математичне моделювання видалення вологи 3 гранули}

\section{Д.М. Корінчук}

Національний технічний університет Украӥни “Київський політехнічний інститут імені Ігоря Сікорського”, Київ, Україна

При сучасних світових тенденціях щодо зростання споживання продукції різних галузей промисловості та екологічній ситуації гостро постає проблема раціонального використання в промисловому виробництві енергетичних та сировинних ресурсів 3 метою одержання максимальної кількості готового продукту заданої якості. Важливим етапом вирішення цієї задачі є створення адекватної математичної моделі процесу. Розроблена спрощена модель процесу зневоднення плівки водного розчину на поверхні одиничної гранули при виробництві багатошарових композитів в сушарці-грануляторі.

Моделювання зневоднення гранули включає аналіз розподілу теплоти в матеріалі сферичної форми та в плівці рідини (теплообмін), що вкриває сферу, і процес випаровування плівки суміші (масообмін), що протікають одночасно.

\section{Вступ}

Широке впровадження нових енергоощадних технологій є невід'ємною частиною науково-технічного прогресу. При сучасних світових тенденціях щодо зростання споживання продукції різних галузей промисловості та погіршення екологічної ситуації гостро постає проблема раціонального використання у виробництві енергетичних та сировинних ресурсів із метою одержання максимальної кількості готового продукту заданої якості.
Мета роботи. Замість багатостадійних процесів сушіння в переробній промисловості знайшли застосування технології гранулювання із псевдозрідженим шаром, що дозволяють об'єднувати в одному апараті усі стадії процесу: випарювання вихідного розчину, кристалізацію, а також сушіння продукту із одночасним гранулоутворенням. Важливим етапом розв'язання такої багатостадійної задачі $\epsilon$ створення адекватної математичної моделі процесу. 


\section{Матеріали та методи дослідження}

Моделювання зневоднення гранули включає аналіз розподілу теплоти в матеріалі сферичної форми та в плівці рідини (теплообмін), що вкриває сферу, та процес випаровування плівки суміші (масообмін), що відбуваються одночасно.

Модель зневоднення одиничної гранули в загальному випадку [1] пов'язана із розв'язанням складної задачі руху двофазної газорідинної суміші при наявності фазового переходу та одночасного перенесення теплоти в трьохфазній системі. Ця задача $є$ нелінійною та ускладнюється необхідністю врахування кінетики фазового перетворення та міжфазного теплообміну, капілярних явищ, що викликають перетікання рідини в порах, а також десорбції або переходу хімічно зв'язаної рідини у вільний стан [2]. Однак ці моделі також містять велику кількість невідомих величин, що входять в нелінійні диференціальні рівняння, розв'язки яких можуть бути отримані лише в частковому випадку та мають громіздкий вигляд, що ускладнює їх практичне застосування. Існує ряд спрощених моделей, що враховують основні особливості гранулювання та дозволяють отримати результати, що достатні для практичного застосування.

Моделі температурного розподілу при гранулюванні у псевдозрідженому шарі представлені в [3]. Автори мають припущення, що в перетині, де гранула перебуває у стані вітання, температура $є$ постійною. Також температура є незмінною на поверхні гранули протягом усього процесу нагрівання. За цією моделлю визначається радіальний розподіл температури в будь-який момент часу.

Для дослідження особливостей випаровування плівки рідини можна використати досвід моделювання випаровування одиничних крапель. Ця проблема широко висвітлена авторами [4], що наводять моделі сушіння крапель на основі балансових рівнянь та спільних розв'язків диференціальних рівнянь дифузії та теплопровідності. У моделі сушіння сферичної частинки допускається, що випаровування рідини відбувається головним чином у вузькій зоні, що поширюється по мірі сушіння в глибину матеріалу.

Враховуючи в нашому випадку наявність процесів випаровування та кипіння, розв'язок задачі тепломасообміну на границі рідкої та газової фази в поєднанні з вирішенням задачі нагрівання гранули та плівки рідини робить можливим визначення часу зневоднення та описання кінетики процесу.

Розглянемо процес зневоднення плівки водного розчину на поверхні одиничної гранули. Припустимо, що гранула має сферичну форму радіусом $R_{1}$ і в початковий момент часу $\tau_{0}$ нагріта до температури $T_{1}$; гранула рівномірно вкрита шаром плівки товщиною $\delta$ з температурою $T_{2}$; температура навколишнього середовища постійна протягом усього часу зневоднення і становить $T_{3}$ (рис. 1a). Вважаємо гранулу ізотропним твердим тілом однакового складу по всьому об'єму. Температура в будь-якій точці гранули є функцією часу $\tau$ і радіусу r. Рідина нагрівається та випаровується за рахунок теплоти, що отримана від попередньо нагрітої гранули та від теплоносія. В початковий момент часу температура гранули на межі $R_{1}$ тверда фаза - piдина нижча за температуру теплоносія на межі $R_{2}$ рідина - газ та знижується при подальшому теплообміні. Тому для спрощення задачі тепломасообміном поміж гранулою та розчином можна знехтувати. Вважаємо, що підведення теплоти здійснюється рівномірно по всій поверхні від навколишнього середовища.

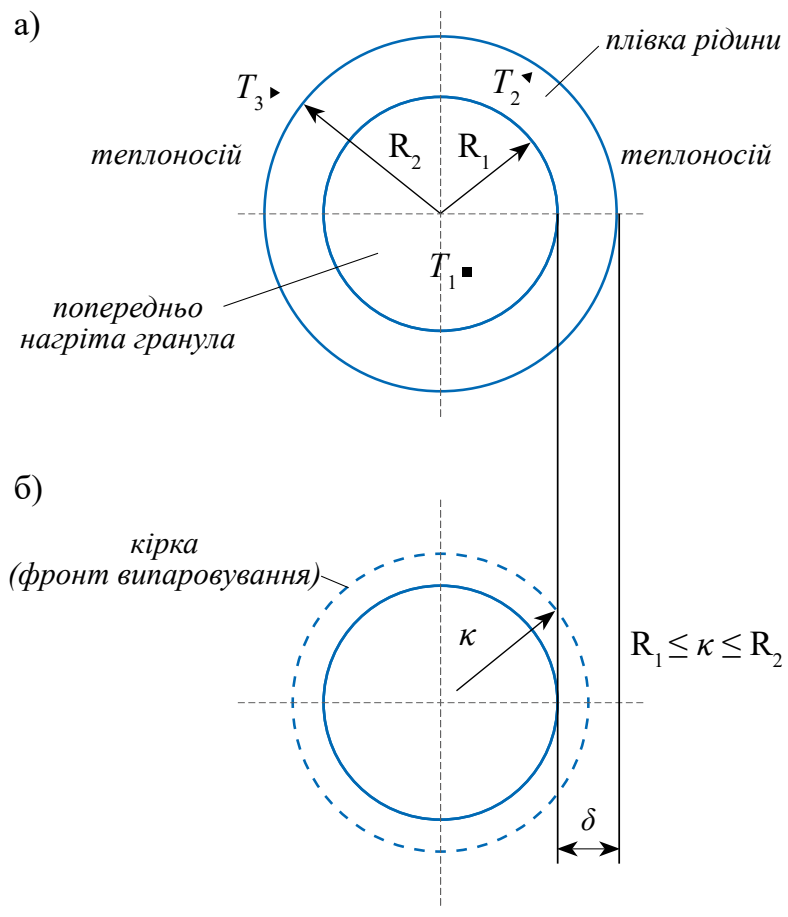

Рис. 1. Спрощена схема фізичної моделі процесу зневоднення гранули:

а) початковий момент часу;

б) поточний момент часу

В роботі [4] зазначено, що зона випаровування рухається в напрямку центру гранули, утворюючи зневоднену кірку. В нашому випадку вважаємо кірку паропроникненою, що не впливає на масообмін. За аналогією $з$ процесами, що пов'язані з рухом межі розділу фаз, можна припустити, що випаровування рідини відбувається головним чином у вузь- 
кій зоні, що розділяє області, зайняті парою (кірка) та розчином. Ширина зони випаровування визначається характерним розміром пір кірки, капілярними силами, а також співвідношенням поміж теплотою, що витрачається на нагрівання розчину та теплотою пароутворення. При зазначених вище умовах ширина зони випаровування $є$ значно меншою характерного розміру гранули. Таким чином цю зону можна замінити фронтом випаровування, а іiі товщиною знехтувати.

Вважаємо, що випаровування протікає в межах товщини $\delta$ (рис. 1б). Під час заглиблення фронту випаровування існує дві області: суха (кірка) та волога (розчин). В сухій області переміщується тільки пара, а вологість дорівнює нулю. А в вологій області концентрація розчину залишається незмінною і дорівнює початковій.

3 урахуванням зроблених припущень математична модель зневоднення плівки водного розчину на поверхні одиничної гранули формулюється наступним чином.

Розподіл температури в межах гранули та плівки описується рівнянням

$$
\frac{\partial T}{\partial \tau}=a\left(\frac{\partial^{2} T}{\partial r^{2}}+\frac{2}{r} \frac{\partial T}{\partial r}\right),
$$

3 початковими умовами:

$$
\begin{array}{ccc}
\left.T\right|_{\tau=0}=T_{1} & \text { npu } & 0 \leq r \leq R_{1}, \\
\left.T\right|_{\tau=0}=T_{2} & n p u & R_{1} \leq r \leq R_{2},
\end{array}
$$

3 граничними умовами:

$$
\begin{gathered}
\left.\frac{\partial T}{\partial r}\right|_{r=0}=0, \\
\left.T\right|_{r=R_{1}-\varepsilon}=\left.T\right|_{r=R_{1}+\varepsilon}, \\
\left.\lambda_{1} \frac{\partial T}{\partial r}\right|_{r=R_{1}}=\left.\lambda_{2} \frac{\partial T}{\partial r}\right|_{r=R_{1}}, \\
\left.\lambda \frac{\partial T}{\partial r}\right|_{r=\kappa}=a\left(T-T_{3}\right) .
\end{gathered}
$$

Рівняння балансу теплоти і вологи в межах фронту випаровування:

$$
\begin{aligned}
& 4 \pi \kappa^{2} \alpha_{2} \Delta T=4 \pi \kappa^{2} \frac{d \kappa}{d \tau} \rho(1-c) L, \\
& \mathrm{R}_{1} \leq \kappa \leq \mathrm{R}_{2} .
\end{aligned}
$$

де:

$a$ - коефіцієнт температуропровідності, $\mathrm{m}^{2} / \mathrm{c}$;

$c$ - масова концентрація розчину, кг/кг;

$L$ - питома теплота пароутворення, Дж/кг;

$T$ - температура, К;

$r$ - поточний радіус, м;

$\alpha$ - коефіцієнт тепловіддачі, Вт/м²;

$\varepsilon$ - нескінченно мала величина;

$\kappa$ - радіус фронту випаровування, м;

$t$ - час, c;

$\lambda$ - коефіцієнт теплопровідності, Вт/(м·К);

$\rho-$ густина, кг $/ \mathrm{M}^{3}$.

Індекси:

1 - для гранули;

2 - для плівки розчину;

3 - для теплоносія.

\section{Результати та їх обговорення}

Система рівнянь розв'язується методом кінцевих різниць по явній схемі в програмному пакеті MathLab. Температура в точці, що передує точці фронту випаровування при русі фронту, визначається інтерполяцією за неявною схемою. Результати розв'язання математичної моделі для гранули сульфату амонію діаметром 3 мм, що попередньо нагріта до температури $90^{\circ} \mathrm{C}$, температури розчину та теплоносія, відповідно, $20^{\circ} \mathrm{C}$ та $100^{\circ} \mathrm{C}$ представлені на діаграмі (рис. 2).

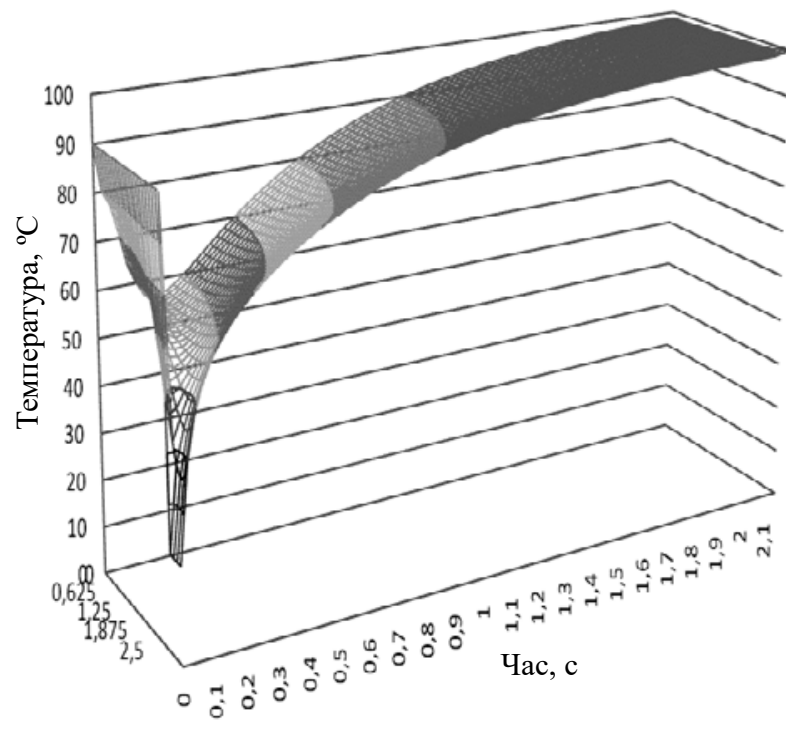

Рис. 2. Результати залежності температури гранули сульфату амонію від часу в перетині випаровування 
Розрахунковий час сушіння складає 2,15 с, що збігається 3 результатами експериментальних досліджень кафедри МАХНВ НТУУ «КПІ імені Ігоря Сікорського».

\section{Висновки}

Розроблена спрощена модель процесу зневоднення плівки водного розчину на поверхні одиничної гранули. Дана модель дозволяє з достатньою, для інженерних розрахунків, точністю визначити час зневоднення в багатошаровій структурі гранулятів.

Результати можуть бути використані на стадіях проектування та опрацювання режимів роботи гранулятора.

\section{References}

1. Бабенко, В.Е., Буевич, Ю.А., Шепчук, Н.М. Квазистационарный режим сушки сферицескойчастицы. Теоретические основы химической технологии. - Т.9, №2. - М.: «Наука». 1975. - С. 274 - 277.
2. Склабінський, В.I., Кочергін, М.О. Створення гранул пористої структури аміачної селітри. Вплив температури навколишнього середовища. Хімічна промисловість України. - 2007. - № 3. C. 22 - 24.

3. Долинский, А.А., Малечкая, К.Д., Шморгун, В.В. Кинетика и технология сушки распылением. К.: Наук. думка. - 1987. - 224 с.

4. Коринчук, Д.Н. Модель высокотемпературной сушки торфяных частиц и ее экспериментальное подтверждение. - СЭТТ-2005. - М.: МЭИ. - 2005. T. 2. - С. 225 - 229. 